\title{
Composition and spatial distribution of subtidal Decapoda on the "Reef Coast", northeastern Brazil, evaluated through a low-impact visual census technique
}

Bruno W. Giraldes, Petrônio A. Coelho Filho and Petrônio A. Coelho ${ }^{\dagger}$

(BWG) (PAC) Laboratório de Carcinologia, Departamento de Oceanografia da Universidade Federal de Pernambuco (MOUFPE), Recife, PE, Brazil. ‘in memoriam. E-mail: b.w.giraldes@hotmail.com (PACF) Departamento de Engenharia de Pesca, Universidade Federal de Alagoas, Penedo, AL,

Brazil. E-mail: petroniocoelhofilho@gmail.com

\section{Abstract}

This study investigated the composition and spatial distribution of the sublittoral decapods on the reefs of Porto de Galinhas Beach, southern coast of Pernambuco, Brazil, through the Underwater Visual Census technique. Data were collected monthly, at night during full-moon tides in low tide periods from June 2004 to May 2005, using SCUBA diving and a visual census with a fixed belt transect $(20 \mathrm{~m}$ long). Three sampling areas were defined: Confined Waters (low hydrodynamics) with shallow sites (up to $2.5 \mathrm{~m}$ deep); Semi-open Water (3 to $6 \mathrm{~m}$ deep), influenced by waves and tidal currents (moderate hydrodynamics); and Open Water (7 to 10 $\mathrm{m}$ deep), in the breaker zone (high hydrodynamics). A total of 6,287 individuals of 34 species belonging to the infraorders Brachyura (19 species), Achelata and Anomura (5 species each), Caridea (3 species), and Stenopodidea and Astacidea (1 species each) were collected. Two decapod assemblages were distinguished: in a habitat with low hydrodynamics and shallow (Confined) water; and in a habitat with moderate to high hydrodynamics and depths of 3 to $10 \mathrm{~m}$ (Semi-open and Open water). At the sites with high hydrodynamics, i.e., the Open-water Area in the breaker zone, decapod diversity was significantly lower than in the other, protected areas on the reef bench. These results suggest that the distribution of subtidal decapods on coastal reefs is influenced by depth and exposure to water stress caused by waves and currents (hydrodynamics). The visual census technique with SCUBA proved to be suitable for ecological studies on subtidal decapods.

Key Words: decapods, ecology, reef fauna, SCUBA diver, visual census.

\section{Introduction}

Among marine ecosystems, coral reefs show the highest known diversity of species (Dubinsky and Stambler, 2011; Huang et al., 2011). Brazil has the only coral reefs in the South Atlantic, and one of the bestdeveloped reef communities is the coastal reefs of northeastern Brazil (Leão et al., 2003).
Described by Laborel (1970) as the "Côte des Arrecifes" or Reef Coast, these reefs are the main coral formations between $8^{\circ} \mathrm{S}$ and $9^{\circ} \mathrm{S}$ and have a distinct morphology (Dominguez et al., 1990; Maida and Ferreira, 1997). The reefs are formed by rows of sandstone, generally parallel to the coast, which serve as a substrate for seaweeds and corals (Manso et al., 2003). The corals grow on the sandstone 
line, upward (toward light) to the upper limit of the subtidal zone (often protruding from the water) and expand laterally from the top, forming densely aggregated structures and an interconnected cave system beneath the reef surface. The depth of the reef structures rarely exceeds 10 m (Laborel, 1970; Dominguez et al., 1990; Maida and Ferreira, 1997). Similarly to reefs elsewhere, in Brazil these habitat is subject to intense anthropogenic pressure, aggravated by their proximity to shore (Castro and Pires, 2001; Feitosa et al., 2002; Fernandes et al., 2005; Barradas et al., 2010; Sarmento et al., 2011).

On hard bottoms such as coral reefs, the decapod crustaceans are one of the most important groups of benthic macrofauna (Abele, 1974; 1976; Abele and Patton, 1976; Martínez-Iglesias and García-Raso, 1999; Alves et al., 2006). They range from inconspicuous to large forms, including shrimps, lobsters and crabs, and are distinguished by their high diversity and their importance in fisheries and trophic dynamics in these environments (Randall, 1967; Dubinsky and Stambler, 2011). The number of studies of diversity and distribution patterns of decapods on coral reefs is still relatively low, probably because these crustaceans have cryptic habits and live hidden during the day in burrows, crevices and caves (Barreto and Katsuragawa, 2008; Igarashi, 2010; Dubinsky and Stambler, 2011), limiting collection and observation.

The Underwater Visual Census (UVC) is a direct sampling technique with low impact, which has been used in several ecological and behavioral studies on marine communities (Willis, 2001; Hill and Wilkinson, 2004; Bakus, 2007; Vanderklift et al., 2007; Seytre and Francour, 2008; Denitto et al., 2009; Mellin et al., 2009; Oliveira et al., 2011), mainly in protected and fragile areas such as coral-reef environments (Edmunds et al., 2005; Marshall and Schuttenberg, 2006; Wilson et al., 2007; Dubinsky and Stambler, 2011).

This study investigated the composition and spatial distribution of the sublittoral decapods on the coastal reef of Porto de Galinhas Beach, northeastern Brazil, one of the main formations of the Reef Coast. The study was conducted by means of the Underwater Visual Census technique, and included areas with different depths and hydrodynamics.

\section{Material and Methods}

\section{Study area}

The study was carried out on the coral reefs of Porto de Galinhas ( $8^{\circ} 30^{\prime} 07^{\prime \prime}$ $8^{\circ} 30^{\prime} 54^{\prime \prime} \mathrm{S}$ and $35^{\circ} 00^{\prime} 08^{\prime \prime}-34^{\circ} 59^{\prime} 47^{\prime \prime} \mathrm{W}$ ) (Fig. 1). These reefs have the typical characteristics described for the Reef Coast (Laborel, 1970; Dominguez et al., 1990; Maida and Ferreira, 1997) (Fig. 1), and are one of the main tourist attractions on the Brazilian coast (MMA/ SECTMA/CPRH, 2003). The Porto de Galinhas reef bench is in direct contact with the shore, which mixes beach and reef ecosystems during low tide when the reef bench emerges, exposing the intertidal zone. The outcropping reef acts as a barrier to the waves breaking in the outer areas. During low tide, the emerged reef bench forms the three areas sampled in this study: A) Confined Water (pools protected by the reefs); B) Semi-open Water (channels crossing the reef bench); and C) Open Water (in the breaker areas) (Fig. 2).

The Confined Waters area (A) is close to the beach and shallow (to $2.5 \mathrm{~m}$ deep), and has almost no current and waves (hydrodynamics). This area is exposed to weak currents and waves only during high tide and neap tides (Fig. 2).

The Semi-open Waters area (B) is mainly in the channels connecting the open sea with the protected water inside the reef bench. With depths between 3 to $6 \mathrm{~m}$, this area is influenced by waves and tidal currents (moderate hydrodynamics). During neap high tide, the current is strong and the area is subject to indirect wave influence (Fig. 2).

The Open Water area $(\mathrm{C})$ is in the outer areas of the reef bench, exactly in the breakingwave zone. Around 7 to $10 \mathrm{~m}$ deep, this area shows strong hydrodynamics during both spring and neap tides, and at high and low tide (Fig. 2). 


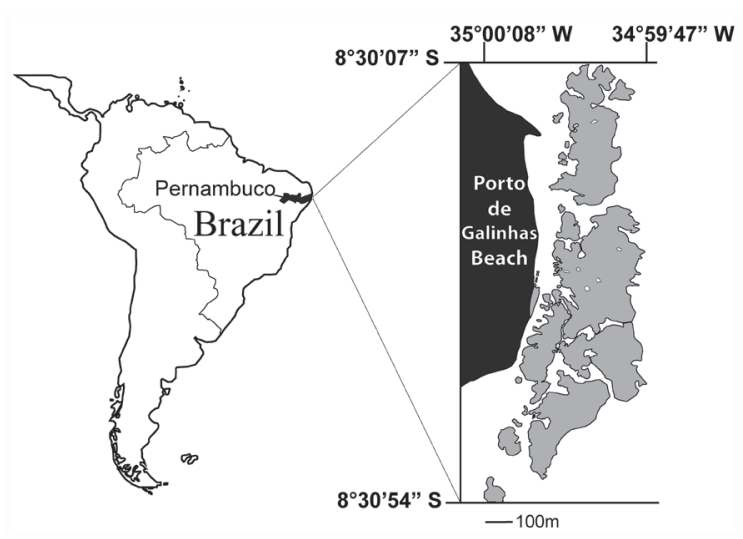

Figure 1. Reef area studied on Porto de Galinhas Beach, state of Pernambuco, northeastern Brazil.

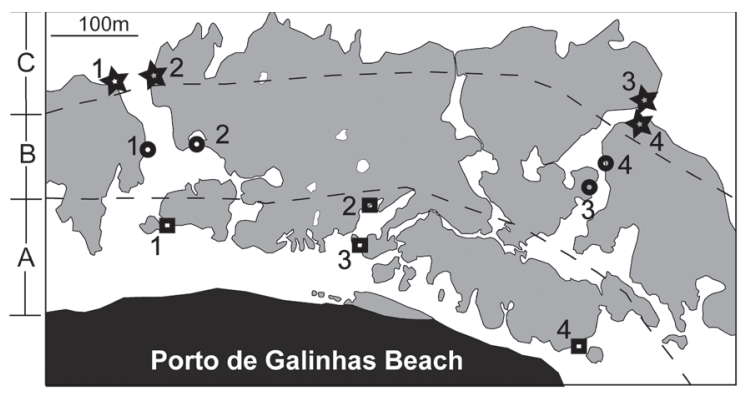

Figure 2. Reef area studied on Porto de Galinhas Beach, Pernambuco, Brazil, showing the four sampling sites in the three areas. Confined Water (sites A1 - A4) (square); Semi-open Water (sites B1 - B4) (circle); and Open Water (sites C1 - C4) (star).

\section{Data Collection}

The data were collected monthly, at night during the full-moon tide in low tide, from June 2004 through May 2005, by SCUBA diving for $3 \mathrm{~h}$ in each dive session (1.5 $\mathrm{h}$ before until $1.5 \mathrm{~h}$ after low tide), in three sampling areas A) Confined Waters, B) Semi-open Water, and C) Open Water. In each area, four collection points were sampled by counting all individuals by visual census, using fixed belt transects, each $20 \mathrm{~m}$ long, totaling 144 transects during the study period.

The chosen monitoring technique was the strip transect technique (STT) (Brock, 1954) with a $20 \mathrm{~m}$-long transect. The area of this medium-scale sampling is based on the volume and size of the largest individuals covered (Hill and Wilkinson, 2004; Bakus, 2007), in this case the large reptant lobsters of the genus Panulirus White, 1847.

The STT is used by monitoring programs worldwide to study underwater communities (including decapods), such as the Australian Institute of Marine Science Longterm Monitoring Program (AIMS LTMP), the various Pacific monitoring programs (Lincoln-Smith transect), the Reef Check MAQTRAC (Marine Aquarium Trade Coral Reef Monitoring Protocol) Program (Hill and Wilkinson, 2004) and the Victorian Subtidal Reef Monitoring Program (Edmunds et al., 2003; 2005; 2007).

Decapods were visually identified in situ by trained divers. The training used the following protocol: 1) each species wasidentified in situ during night dives; 2) the species was recorded on an underwater clipboard; 3) the specimen was hand-collected (with tweezers and dip nets); and 4) the species identification was confirmed through appropriate references. This procedure was repeated until the diver was confident in identifying each species.

Some decapods were not collected because their usual and known color pattern and morphological characteristics allow easy identification in situ. These included some commercially important species used for food (Cervigón et al., 1992) or the aquarium trade (Calado et al., 2003; Gasparini et al., 2005).

\section{Data analysis}

The following estimated ecological indexes were based on Krebs (1994; 1998) Dajoz (2005) and Odum and Barrett (2007). Abundance - total number of individuals and Frequency of occurrence (\%) - percentage of occurrence of a given species in relation to the total number of transects or areas, calculated by $\mathrm{Fa}=(\mathrm{Pa} \times 100) / \mathrm{P}$, where: $\mathrm{Fa}=$ frequency of the species, $\mathrm{Pa}=$ number of transects in which the species is present, and $\mathrm{P}=$ total number of samples or stations. Based on the frequency value, the species were considered rare $(\mathrm{Fa}$ $<10 \%)$, common $(10 \% \leq \mathrm{Fa}<50 \%)$, or constant $(50 \% \leq \mathrm{Fa} \leq 100 \%)$. Dominance $(\%)$ - expresses the ratio between the number of individuals of a given species and the number of individuals of all species, calculated by the formula $\mathrm{Da}=(\mathrm{Na} \times 100) / \mathrm{Nt}$, where $\mathrm{Da}=$ Dominance of the given species, $\mathrm{Na}=$ number of individuals of the species, and $\mathrm{Nt}=$ number 
of individuals of all species. Diversity $\left(\mathrm{H}^{\prime}\right)$ Shannon-Wiener diversity index (Shannon and Weaver, 1949), considered slightly diverse $\left(\mathrm{H}^{\prime}<1\right.$ bits.ind $\left.{ }^{-1}\right)$, diverse $\left(1 \leq \mathrm{H}^{\prime}<2\right.$ bits. ind $\left.^{-1}\right)$, and very diverse $\left(2 \leq \mathrm{H}^{\prime}<3\right.$ bits.ind ${ }^{-}$ $\left.{ }^{1}\right)$. Equitability $(J ')$ - the Pielou equitability index (Pielou, 1966), ranging from 0 (lowest uniformity) to 1 (maximum uniformity).

To analyze the main groups of species according to area (Confined, Semi-open and Open), we performed a cluster analysis and generated a dendrogram with the species and the degree of similarity of each group, using the Bray-Curtis similarity coefficient (Bray and Curtis, 1957) based on the abundance of the most important species (excluding rare species with fewer than 10 individuals found).

To evaluate differences between the means for abundance, diversity and equitability in the study areas, the nonparametric MannWhitney test was used (Zar, 1999), with a significance level of $5 \%$. To check the similarity in composition and abundance with respect to the above variables, a NonMetric Multidimensional Scaling (NMDS) ordination analysis was performed (Clarke, 1993; Clarke and Warwick, 1994).

The similarity matrix was constructed using the Bray-Curtis similarity coefficient (Bray and Curtis, 1957) based on the abundance of the most important species (excluding rare species with fewer than five individuals found). The bifactorial Analysis of Similarity (ANOSIM) evaluated the existence of significant differences in the fauna composition according to area, through the NMDS analysis matrix. $R$ values higher than 0.5 and with a significance level less than $5 \%$ were considered statistically significant. All calculations were performed using the statistical software package Primer ${ }^{\circledast} 6.0$ (Clarke and Gorley, 2001).

\section{Results}

\section{Composition}

A total of 34 species $(5.3 \pm 1.8$ species/ transect) were identified during the study period, belonging to infraorders Brachyura (19 species), Achelata and Anomura (5 species each), Caridea (3 species), and Stenopodidea and Astacidea (1 species each). Among the Brachyura, the family Mithracidae was the most important (5 species); among the Achelata, Palinuridae was best represented (3 species); and Diogenidae among the Anomura (4 species) (Table 1 ).

In all, 29 species occurred in the Confined, 25 in the Semi-open, and 22 in the Open area. The species of infraorders Stenopodidea, Caridea, Achelata and Astacidea occurred in all three areas, but were more abundant, frequent, and dominant in the Semi-open and Open areas. Anomurans were best represented in the Confined area, with the exception of Cancellus ornatus Benedict, 1901, which occurred only in the Semi-open and Open areas. Brachyurans were also best represented in the Confined area (16 species); the number of species declined with the distance from shore, with 11 species in the Semi-open and 9 in the Open area. The caridean Cinetorhynchus rigens and the lobster Panulirus echinatus were the dominant and abundant species in the entire reef area (Table $1)$.

\section{Abundance}

We observed 6,287 individuals (43.6 \pm 24.9 individuals/transect) during the study. $C$. rigens was the most abundant species with 3,118 individuals $(21.7 \pm 9.5$ per transect $)$, followed by the brachyuran Mithraculus forceps with 1,357 individuals $(17.3 \pm 9.4$ per transect) and P. echinatus with 1,139 (7.9 \pm 7.1 per transect).

The estimated abundances in the three study areas were significantly similar $\left(\mathrm{p}_{\mathrm{AB}}=\right.$ 0.55; $\left.\mathrm{p}_{\mathrm{AC}}=0.88 ; \mathrm{p}_{\mathrm{BC}}=0.55\right)$. In the Confined area, 2,076 individuals were found (43.2 \pm 22.7 individuals/transect); in the Semi-open, 1,986 individuals $(41.4 \pm 23.6$ individuals/ transect); and in the Open, 2,225 individuals (46.3 \pm 28.2 individuals/transect) (Fig. 3). Cinetorhynchus rigens was the most abundant species in the Semi-open $(25.8 \pm 17.9$ individuals/transect) and Open (31.3 \pm 22.1 individuals per transect); in the Confined area, 
Table 1 - Abundance, Dominance and Frequency of each species found in the subtidal of the Porto de Galinhas reef bench, Pernambuco, northeastern Brazil, by sampling areas: Confined Water (A), Semi-open Water (B), and Open Water $(\mathrm{C})$. Relative abundance (Ab) with the mean number of individuals per transect. Dominance (Do) with the dominance percentage. Frequency of occurrence indicated by the color of the cells: Rare (white), Common (gray), and Constant (dark gray). *indicates absence of the species.

\begin{tabular}{|c|c|c|c|c|c|c|}
\hline \multirow{2}{*}{ Species } & \multicolumn{2}{|c|}{ Confined } & \multicolumn{2}{|c|}{ Semi-open } & \multicolumn{2}{|c|}{ Open } \\
\hline & $\mathrm{Ab}$ & Do & $\mathbf{A b}$ & Do & $\mathbf{A b}$ & Do \\
\hline \multicolumn{7}{|l|}{ STENOPODIDEA } \\
\hline \multicolumn{7}{|l|}{ Stenopodidae } \\
\hline Stenopus hispidus (Olivier, 1811) & 0.2 & $<1$ & 0.7 & 2 & 0.5 & 1 \\
\hline \multicolumn{7}{|l|}{ CARIDEA } \\
\hline \multicolumn{7}{|l|}{ Rhynchocinetidae } \\
\hline Cinetorhynchus rigens (Gordon, 1936) & 7.8 & 18 & 25.8 & 62 & 31.3 & 68 \\
\hline \multicolumn{7}{|l|}{ Palaemonidae } \\
\hline Brachycarpus biunguiculatus (Lucas, 1849) & 0.1 & $<1$ & 0.2 & $<1$ & 0.3 & 1 \\
\hline \multicolumn{7}{|l|}{ Barbouriidae } \\
\hline Janicea antiguensis (Chace, 1972) & 0.3 & 1 & 0.9 & 2 & 1.1 & 2 \\
\hline \multicolumn{7}{|l|}{ ASTACIDEA } \\
\hline \multicolumn{7}{|l|}{ Enoplometopidae } \\
\hline Enoplometopus antillensis (Lütken, 1865) & $<0.1$ & $<1$ & $<0.1$ & $<1$ & 0.1 & $<1$ \\
\hline \multicolumn{7}{|l|}{ ACHELATA } \\
\hline \multicolumn{7}{|l|}{ Palinuridae } \\
\hline Palinurellus gundlachi von Martens, 1878 & 0.1 & $<1$ & 0.2 & 1 & 0.2 & $<1$ \\
\hline Panulirus argus (Latreille, 1804) & $<0.1$ & $<1$ & 0.2 & $<1$ & 0.4 & 1 \\
\hline Panulirus echinatus Smith, 1869 & 2.8 & 7 & 10.1 & 24 & 10.8 & 23 \\
\hline Panulirus laevicauda (Latreille, 1817) & $<0.1$ & $<1$ & $<0.1$ & $<1$ & $<0.1$ & $<1$ \\
\hline \multicolumn{7}{|l|}{ Scyllaridae } \\
\hline Parribacus antarcticus (Lund, 1793) & 0.2 & 1 & 0.2 & $<1$ & 0.1 & $<1$ \\
\hline ANOMURA & & & & & & \\
\hline Diogenidae & & & & & & \\
\hline Calcinus tibicen (Herbst, 1791) & 0.5 & 1 & $<0.1$ & $<1$ & 0.1 & $<1$ \\
\hline Cancellus ornatus Benedict, 1901 & $*$ & * & $<0.1$ & $<1$ & $<0.1$ & $<1$ \\
\hline Dardanus venosus (H. Milne Edwards, 1848) & $<0.1$ & $<1$ & * & * & $*$ & * \\
\hline Paguristes erythrops Holthuis, 1959 & $<0.1$ & $<1$ & 0.1 & $<1$ & * & * \\
\hline Paguridae & & & & & & \\
\hline Pagurus provenzanoi Forest and de Saint Laurent, 1968 & 0.8 & 2 & 0.1 & $<1$ & $<0.1$ & $<1$ \\
\hline BRACHYURA & & & & & & \\
\hline Dromiidae & & & & & & \\
\hline Dromia erythropus (Edwards, 1771) & $<0.1$ & $<1$ & * & $*$ & * & * \\
\hline Calappidae & & & & & & \\
\hline Calappa ocellata Holthuis, 1958 & * & * & $<0.1$ & $<1$ & $<0.1$ & $<1$ \\
\hline Carpiliidae & & & & & & \\
\hline Carpilius corallinus (Herbst, 1783) & * & * & $<0.1$ & $<1$ & * & * \\
\hline Menippidae & & & & & & \\
\hline Menippe nodifrons Stimpson, 1859 & 0.2 & $<1$ & 0.2 & $<1$ & 0.1 & $<1$ \\
\hline Leucosiidae & & & & & & \\
\hline Lithadia conica (Coelho, 1973) & $<0.1$ & $<1$ & * & $*$ & * & * \\
\hline Epialtidae & & & & & & \\
\hline Acanthonyx dissimulatus Coelho, 1993 & $<0.1$ & $<1$ & * & $*$ & * & * \\
\hline Pelia rotunda A. Milne-Edwards, 1875 & 0.1 & $<1$ & $<0.1$ & $<1$ & * & * \\
\hline Pitho lherminieri (Desbonne, in Desbonne and Schramm, 1867) & $<0.1$ & $<1$ & * & * & * & * \\
\hline Inachidae & & & & & & \\
\hline Stenorhynchus seticornis (Herbst, 1788) & 0.1 & $<1$ & 0.2 & 1 & 0.5 & 1 \\
\hline Majidae & & & & & & \\
\hline Microphrys bicornutus (Latreille, 1825) & 1.6 & 4 & $<0.1$ & $<1$ & $<0.1$ & $<1$ \\
\hline Mithraculus forceps A. Milne-Edwards, 1875 & 26.2 & 61 & 1.9 & 4 & 0.3 & 1 \\
\hline Mithrax braziliensis Rathbun, 1892 & 0.7 & 2 & 0.2 & $<1$ & 0.2 & $<1$ \\
\hline Mithrax hemphilli Rathbun, 1892 & 0.5 & 1 & $<0.1$ & $<1$ & $<0.1$ & $<1$ \\
\hline Mithrax hispidus (Herbst, 1790) & 0.4 & 1 & 0.2 & 1 & 0.2 & $<1$ \\
\hline Portunidae & & & & & & \\
\hline Callinectes marginatus (A. Milne-Edwards, 1861) & 0.1 & $<1$ & * & $*$ & * & * \\
\hline Charybdis hellerii (A. Milne-Edwards, 1867) & $<0.1$ & $<1$ & $<0.1$ & $<1$ & * & * \\
\hline Domeciidae & & & & & & \\
\hline Domecia acanthophora (Desbonne, in Desbonne and Schramm, 1867) & 0.4 & 1 & 0.1 & $<1$ & * & * \\
\hline Xanthidae & & & & & & \\
\hline Platypodiella spectabilis (Herbst, 1794) & * & * & * & * & $<0.1$ & $<1$ \\
\hline
\end{tabular}




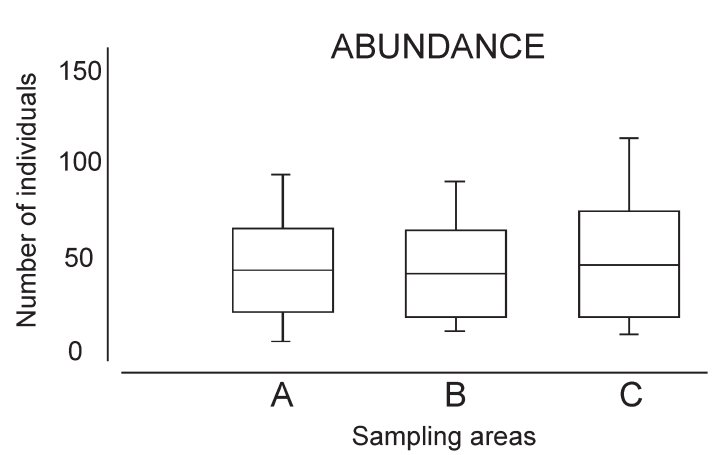

Figure 3. Abundance box plot of decapod species in Porto de Galinhas, Pernambuco, Brazil, showing the values for the three sampling areas: Confined Water (A), Semi-open Water (B) and Open Water (C).

Mithraculus forceps was the most abundant species (26.2 \pm 21.9 individuals/transect) (Table 1).

\section{Frequency}

Three species were constant in the entire study (Cinetorhynchus rigens, Panulirus echinatus and Mithraculus forceps), 14 species were common (the stenopodidean Stenopus hispidus, the carideans Janicea antiguensis and Brachycarpus biunguiculatus, the lobsters Panulirus argus, Parribacus antarcticus and Palinurellus gundlachi, the anomurans Calcinus tibicen and Pagurus provenzanoi and the brachyurans Microphrys bicornutus, Mithrax brasiliensis, Mithrax hemphilli, Mithrax hispidus, Stenorhynchus seticornis and Menippe nodifrons. The other 17 species were rare (Table $1)$.

In the Confined area (A), 3 species were constant (Cinetorhynchus rigens, Panulirus echinatus and Mithraculus forceps), 11 common (Stenopus hispidus, Janicea antiguensis, Parribacus antarcticus, Palinurellus gundlachi, Calcinus tibicen, Pagurus provenzanoi, Microphrys bicornutus, Mithrax brasiliensis, $M$. hemphilli, M. hispidus, and Menippe nodifrons), and 15 were rare, especially the anomuran Dardanus venosus and the brachyurans Dromia erythropus, Pachygrapsus transversus, Pitho lherminieri, Acanthonyx dissimulatus and Lithadia conica which were rare and exclusive to this tide area.

In the Semi-open area (B), four were constant (Janicea antiguensis, Cinetorhynchus rigens, Panulirus echinatus and Mithraculus forceps), eight common (Stenopus hispidus Brachycarpus biunguiculatus, Panulirus argus, Parribacus antarcticus, Palinurellus gundlachi, Menippe nodifrons, Stenorhynchus seticornis, Mithrax brasiliensis and M. hispidus), and 13 species were rare, particularly the brachyuran Carpilius corallinus, which was found exclusively in this area.

In the Open area (C), only Cinetorhynchus rigens and Panulirus echinatus were constant, 11 species were common (Stenopus hispidus, Janicea antiguensis, Brachycarpus biunguiculatus, Panulirus argus, Parribacus antarcticus, Palinurellus gundlachi, Menippe nodifrons, Stenorhynchus seticornis, Mithraculus forceps, Mithrax brasiliensis and $M$. hispidus), and 9 were rare, with the brachyuran Platypodiella spectabilis exclusive to the Open area (Table 1).

\section{Dominance}

Three species dominated, comprising almost $90 \%(89.3 \%)$ of the total individuals: Cinetorhynchus rigens (49.6\%), Mithraculus forceps (21.6\%) and Panulirus echinatus (18.2\%). Seven species showed dominances around 1\% and together accounted for 6.8\% of the individuals found: Stenopus hispidus (1.03\%), Janicea antiguensis (1.8\%), Pagurus provenzanoi (0.7\%), Microphrys bicornutus (1.3\%), Mithrax brasiliensis (0.8\%), M. hispidus $(0.6 \%)$ and Stenorhynchus seticornis $(0.56 \%)$. The 24 remaining species showed dominance lower than $0.5 \%$, and together accounted for $3.9 \%$ of the total number of individuals (Table $1)$.

Mithraculus forceps was the dominant species in Confined Waters (A) (60.5\%), followed by Cinetorhynchus rigens (18\%), Panulirus echinatus (6.5\%), Microphrys bicornutus (3.8\%), P. provenzanoi (1.9\%), and Mithrax brasiliensis (1.5\%); the other 24 species together comprised $7.7 \%$ of the total individuals (Table 1).

Cinetorhynchus rigens (62.4\%) and Panulirus echinatus (24.3\%) dominated the Semi-open Waters (B), followed by Mithraculus forceps (4.5\%), Janicea antiguensis (2.2\%), and Stenopus hispidus (1.6\%); the other 21 

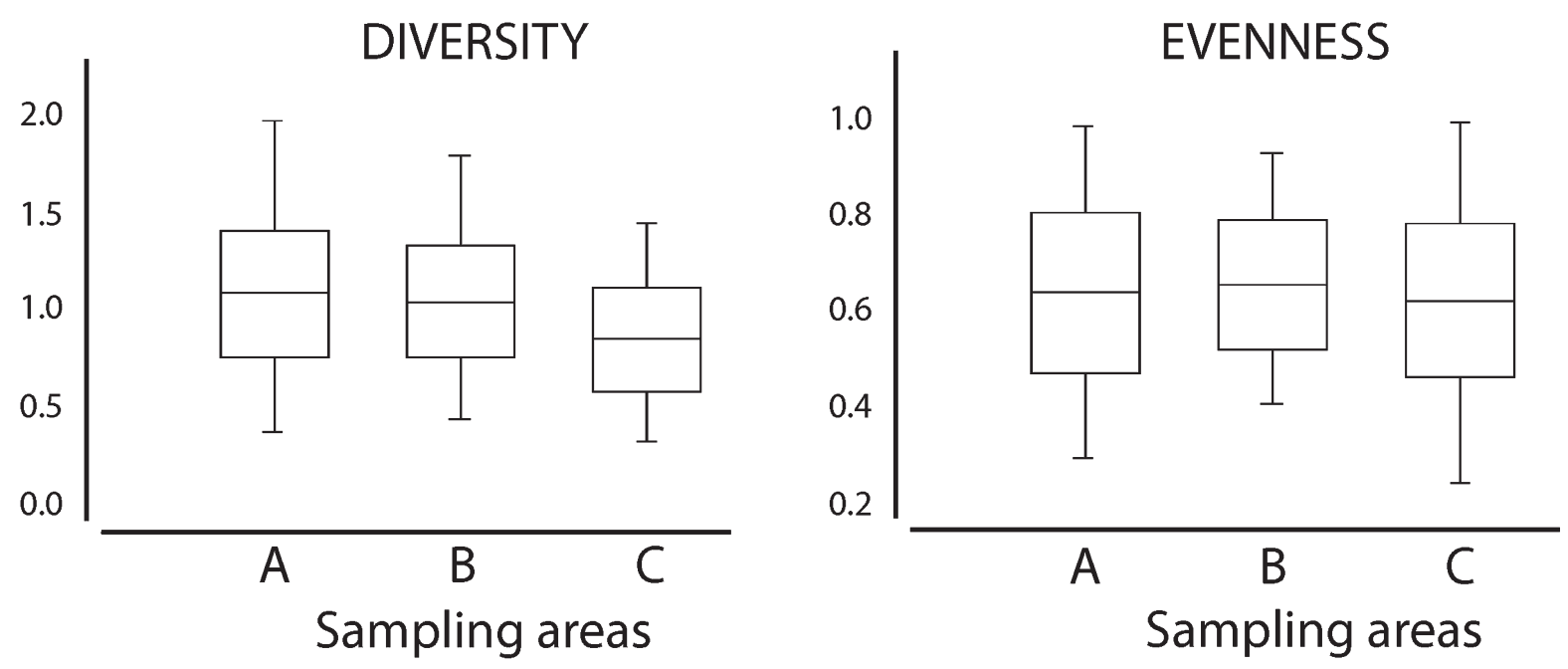

Figure 4. Diversity and equitability box plot of decapod species in Porto de Galinhas, Pernambuco, Brazil, showing the values for the three sampling areas: Confined Water (A), Semi-open Water (B) and Open Water (C).

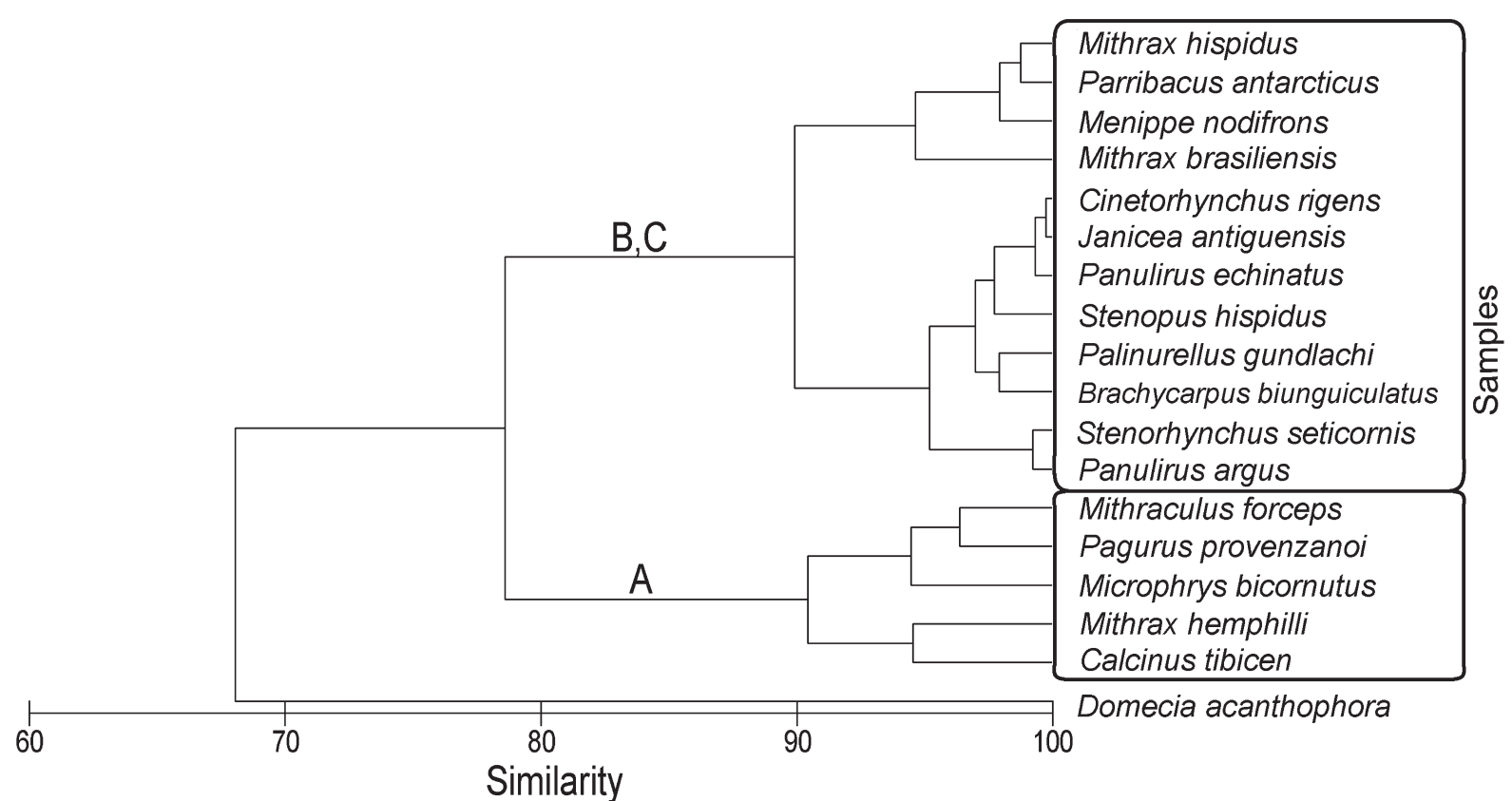

Figure 5. Dendrogram of similarities for the most numerous decapod species in Porto de Galinhas, Pernambuco, Brazil, based on analysis of the three sampling areas: Confined Water (A), Semi-open Water (B) and Open Water (C).

species together comprised $4.9 \%$ of the total individuals. The Open Water area $(\mathrm{C})$ was mainly dominated by Cinetorhynchus rigens (67.6\%) and Panulirus echinatus (23.4\%); the other 20 species contributed $9 \%$ of the total (Table 1).

\section{Diversity and Equitability}

Diversity ranged from 0.4 to 2.0 bits. ind $^{-1}$. In the Confined Water (A) $(1.1 \pm 0.33$ bits.ind ${ }^{-1}$ ) and in the Semi-open Water (B) $\left(1.0 \pm 0.29\right.$ bits.ind $\left.^{-1}\right)$, the diversity was similar $\left(\mathrm{p}_{\mathrm{AB}}=0.5\right)$, but significantly higher than in the Open Water $(\mathrm{C})\left(0.8 \pm 0.27\right.$ bits.ind $\left.^{-1}\right)\left(\mathrm{p}_{\mathrm{AC}}=\right.$ 0.005 and $\left.\mathrm{p}_{\mathrm{BC}}=0.014\right)$ (Fig. 4).

Equitability was relatively high (mean $0.65 \pm 0.1$ ), ranging from 0.25 to 1 , but was similar among the three areas and showed no statistical difference between $(A)$ and $(B)\left(p_{A B}\right.$ $=0.5701),(A)$ and $(C)\left(p_{A C}=0.6029\right)$, or $(B)$ and $(C)\left(p_{B C}=0.2295\right)$ (Fig. 4). 


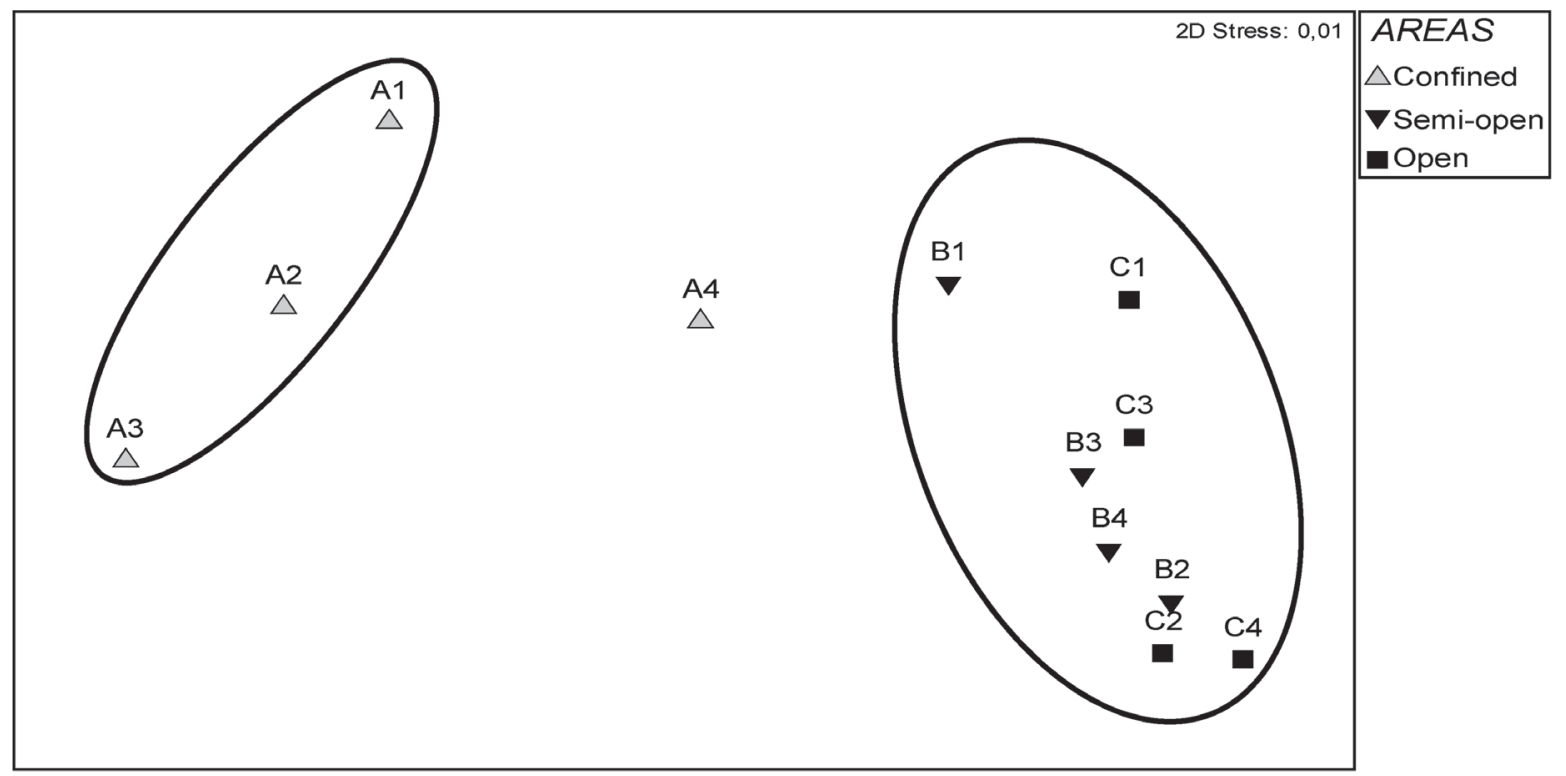

Figure 6. Non-parametric multidimensional scaling (nMDS) based on the similarity matrix of each sampling site per area: Confined Water (sites A1 - A4), Semi-open Water (sites B1 - B4), and Open Water (sites C1 - C4).

\section{Multivariate analysis}

Despite the high similarity (>70\%) indicated by the cluster analysis, three distinct groups were apparent (Fig. 5). The first group was formed by Pagurus provenzanoi, Calcinus tibicen, Mithraculus forceps, Microphrys bicornutus and Mithrax hemphilli and was characteristic of the Confined Water (A). The second group was formed by species characteristic of the Semi-open Water (B) and Open Water (C) together: Stenopus hispidus, Janicea antiguensis, Brachycarpus biunguiculatus, Cinetorhynchus rigens, Palinurellus gundlachi, Panulirus echinatus, Panulirus argus, Parribacus antarcticus, Menippe nodifrons, Stenorhynchus seticornis, Mithrax brasiliensis and M. hispidus. The third group was formed only by the brachyuran Domecia acanthophora.

A similar pattern was found in the MDS for the species distribution, with the formation of two statistically significant groups (Fig. 6): 1 - Open Water $(\mathrm{C})+$ Semi-open Water (B), and 2 - Confined Water $(\mathrm{A})\left(\mathrm{p}_{\mathrm{AB}}=0.03 / \mathrm{R}=0.85\right.$; $\left.\mathrm{p}_{\mathrm{AC}}=0.03 / \mathrm{R}=0.93 ; \mathrm{p}_{\mathrm{BC}}=0.46 / \mathrm{R}=-0.04\right)$. The southernmost point in the Confined Water (A4) was distinct; this point is deeper and less confined than the other points (Fig. 6).

\section{Discussion}

\section{Decapod composition}

The brachyuran crabs are among the most abundant and diverse groups of species on coral reefs (Dubinsky and Stambler, 2011), and in this study comprised $55 \%$ of the total species on the reefs. The ornamental crab Mithraculus forceps was the most dominant and abundant crab, as also found on rocky shores of the southeastern and southern coast of Brazil by SCUBA divers (Gaeta et al., 2011) and manual sampling (Mantelatto et al., 2004; Bouzon and Freire, 2007). The dominance of $M$. forceps in shallow hard-bottom areas is probably due to: short larval stage, high survival rate of juveniles and rapid growth (Rhyne et al., 2005); high reproductive effort and growth stimulated by warm water (Mantelatto et al., 2004; Rhyne et al., 2005; Figueiredo et al., 2008); as well as herbivorous feeding habit (Figueiredo et al., 2008); and possibly effective defense strategies and an absence of large predators.

In addition to $M$. forceps, other brachyurans including Mithrax braziliensis, Mithrax hispidus, Pelia rotunda, Pitho lherminieri, Stenorhynchus seticornis, Pachygrapsus transversus and Menippe nodifrons 
were common on the Porto de Galinhas reef. These species are commonly found associated with algae on coral reefs or rocky shores and coral reefs (Melo, 1996), and were also collected in the daytime by SCUBA divers in southeast and southern Brazil (Mantelatto et al., 2004; Bouzon and Freire, 2007).

Caridean shrimps are also an important group on coral-reef and other hard-bottom ecosystems, including marine and anchialine caves (Hobbs III, 1994; Clark et al., 2008). The caridean Cinetorhynchus rigens was the most abundant and dominant species on the Porto de Galinhas reef, comprising around 50\% of all specimens found during the study. This shrimp is reported from cavernicolous marine environments (Okuno, 1997; Micael et al., 2006) and on the Porto de Galinhas reef was found in crevices in the walls, on cave roofs, and in reef grottos, moving out of the caves at night. Caillaux and Stotz (2003) found a similar pattern for the shrimp Rhynchocinetes typus H. Milne Edwards, 1937 in cavities and caves in Chile. Another very abundant caridean shrimp on the Porto de Galinhas reef was Janicea antiguenis, which is often found in underwater caves and tunnels (Manning and Hart, 1984; Hobbs III, 1994; Udekem d'Acoz, 2001; Wirtz, 2004). The high abundance of $J$. antiguensis and C.rigens in studied reef is probably due to: the studied area present many caves and a large crevicular system below the reef structures, typical habitat for these species (Manning and Hart, 1984; Okuno, 1997; Micael et al., 2006); J. antiguensis and C. rigens have nocturnal habits (Okuno, 1997).

Some species found on this reef deserve particular attention because of their economic and social importance. Brachycarpus biunguiculatus, Cinetorhynchus rigens, Stenopus hispidus, Enoplometopus antillensis, Palinurellus gundlachi, Calcinus tibicen, Domecia acanthophora, Stenorhynchus seticornis, Pelia rotunda, Platypodiella spectabilis, Dardanus venosus, Petrochirus diogenes and Mithraculus forceps are ornamental species popular in the aquarium trade (Calado et al., 2003; Gasparini et al., 2005; Balaji et al., 2009), while the lobsters Panulirus argus, P. laevicauda and P. echinatus are targets of artisanal fishing (Rocha et al., 1997). Many of these species were rare and in low abundance on the reefs, demonstrating the importance of developing local public policies for the management of their catches.

The portunid crab Charybdis hellerii was rare but present in the study area, especially in confined waters. An invasive species originally from the Indo-Pacific, $C$. hellerii is recorded from the Brazilian coast from Maranhão to Santa Catarina, in reefs and estuarine environments (Calado, 1996; Mantelatto and Dias, 1999; Bezerra and Almeida, 2005; Braga et al., 2005; Feres et al., 2007; Coelho et al., 2008; Loebmann et al., 2010; Silva and Barros, 2011). It competes for space and food with native species (Loebmann et al., 2010).

\section{Spatial distribution}

The abundance of decapods showed no statistically significant differences between the sampling areas. However, we expected that decapods found in the shallower and more easily accessed areas on a reef bench that is heavily used by tourists (MMA, SECTMA and CPRH, 2003) would be less abundant and less diverse, especially species with economic value. Surprisingly, these shallower areas showed the highest diversity and abundance, suggesting that the Confined-water areas provide shelter for juveniles and young decapods, as also recorded for the spiny lobsters Panulirus argus and Panulirus echinatus, which use the crevices of coastal reefs as refuges (Barreto and Katsuragawa, 2008; Igarashi, 2010).

Analysis of the faunal assemblage clearly showed the formation of three well-defined groups with different spatial distributions: 1) species found in shallow waters, with maximum depth about $2.5 \mathrm{~m}$ and less-intense hydrodynamics (Confined area); 2) species in deeper locations (3 to $10 \mathrm{~m}$ ), which are subject to some form of wave and tidal stress (Semiopen and Open areas). These findings suggested that hydrodynamics (water confinement) and differences in depth on shallow coastal-reef benches influence the distribution of subtidal 
decapods, and agree with observations by Martínez-Iglesias and García-Raso (1999) and Huang et al. (2011), who included these among the main factors that influence the distribution of benthic invertebrates. The third group was formed by the crab Domecia acanthophora, the only species found only on the fire coral Millepora alcicornis Linnaeus, 1758, showing the importance of inter-specific associations existing on reef ecosystems (Patton, 1967; Criales, 1984; Wirtz and Udekem d'Acoz, 2008; Wirtz et al., 2009).

The assemblage in the Confined area was mainly composed of Brachyura and Anomura. The five most significant (dominant and frequent) species in this area, Calcinus tibicen, Pagurus provenzanoi, Mithraculus forceps, Microphrys bicornutus and Mithrax hemphilli are commonly associated with secondary substrates such as macrophytes, sponges and corals on reefs in northeastern Brazil, and can be collected manually during low tide (Melo, 1996; Almeida et al., 2008; Garcia et al., 2008; Batista et al., 2009). On these reefs, the Confined area, with its shallow, welllighted pools is favorable for the establishment of secondary substrates such as macrophytes, zooanthids and corals (Maida and Ferreira, 1997; Barradas et al., 2010) and decapod crustaceans are known to be associated with these living substrates (Stevens and Anderson, 2000; Batista et al., 2009; Wirtz et al., 2009).

In the Semi-open area, the decapod assemblage showed intermediate characteristics between the assemblage in the Confined area, composed mainly of brachyuran crabs, and in the Open area, composed mainly by caridean shrimps, suggesting a gradual change in decapod distribution according to depth and hydrodynamics. In the Semi-open area, Stenopus hispidus, Janicea antiguenis and Palinurellus gundlachi were prominent; these species are commonly recorded in caves, tunnels or inaccessible cavities on coastal reefs (Manning and Hart, 1984; Williams, 1984; Melo, 1999). The ornamental shrimp Stenopus hispidus is the most popular shrimp among aquarists (Calado et al., 2003), and probably finds refuge in the caves of the Semi-open area.
The Open-water area in the breaker zone is more exposed to wave action (with stronger hydrodynamics) and showed the lowest decapod diversity, significantly lower than the more-protected areas on the reef bench. The strong hydrodynamics limits the establishment of decapods and other benthic species such as seaweed, sponges and corals (Huang et al., 2011), which serve as living substrates for some decapod species. According to Thiel and Vásquez (2000), the branches and structures of algae are important microhabitats for decapods.

The characteristic species (highest dominance and frequency) for the Open area were caverniculous or crevicular species including Cinetorhynchus rigens, Brachycarpus biunguiculatus, Janicea antiguensis, Enoplometopus antillensis and Palinurellus gundlachi, with adaptations to cave life (winered color and/or long tactile structures), or species with strong structures to hold themselves in the reef structures under wave and current action, such as the ornamental crabs Stenorhynchus seticornis and Platypodiella spectabilis (Hart et al., 1985; Hobbs III, 1994; Iliffe and Bishop, 2007).

Stenorhynchus seticornis is commonly associated with sessile invertebrates (Hayes et al., 1998; 2006; Wirtz et al., 2009), and at Porto de Galinhas, was found associated with the octocoral Carijoa riisei Duchassaing and Michelotti, 1860 in the Semi-open and Open areas. Stenhorhynchus seticornis has an elongated body, which provides perfect camouflage and symbiosis among the octocoral structures. The ornamental crab Platypodiella spectabilis was found on the zooanthid Palythoa caribaeorum Duchassaing and Michelotti, 1860 that commonly covers the flat reef surface in the breaker zone (Barradas et al., 2010), an association also reported by Gleibs et al. (1995) in the Colombian Caribbean Sea. Domecia acanthophora, which was found in this study only on the hydrocoral Millepora alcicornis Linnaeus, 1758, was also recorded on Millepora alcicornis at Parrachos de Maracajaú, northeastern Brazil (Garcia et al., 2008), and on three acroporid 
corals [Acropora cervicornis (Lamarck, 1816), A. palmata (Lamarck, 1816) and A. prolifera (Lamarck, 1816)] in Puerto Rico (Patton, 1967). This association with cnidarians provides the reef crabs protection against predators and the strong tidal currents typical of the Open and Semi-open areas (Williams, 1984).

\section{Acknowledgements}

The authors thank the Acqua Viva Dive Center for dive support, Dr. Janet Reid for English assistance, CNPQ (Conselho Nacional de Desenvolvimento Científico e Tecnológico) and FACEPE (Fundação de Amparo à Ciência e Tecnologia de Pernambuco) for the M.Sc. and PhD scholarship awarded to B.W. Giraldes, and the anonymous reviewers for their suggestions on the text.

\section{References}

Abele, L.G. 1974. Species diversity of decapod crustaceans in marine habitats. Ecology, 55: 156-161.

Abele, L.G. 1976. Comparative Species Composition and Relative Abundance of Decapod Crustaceans in Marine Habitats of Panama. Marine Biology, 38: 263-278.

Abele, L.G. and Patton, W.K. 1976. The size of coral heads and the community biology of associated decapod crustaceans. Journal of Biogeography, 3: 35-47.

Almeida, A.O.; Bezerra, L.E.A.; SouzaFilho, J.F.; Almeida, S.M.; Albuquerque, D.L. and Coelho, P.A. 2008. Decapod and stomatopod crustaceans from Santo Aleixo Island, state of Pernambuco, Brazil. Nauplius, 16(1): 23-41.

Alves, D.F.R.; Cobo, V.J. and Melo, G.A.S. 2006. Extension of the geographical distribution of some brachyuran and porcellanid decapods (Crustacea) to the coast of the State of São Paulo, Brazil. Revista
Brasileira de Zoolologia, 23(4): 1280-1283. Bakus, G.J. 2007. Quantitative Analysis of Marine Biological Communities: Field Biology and Environment. Hoboken, New Jersey, John Wiley \& Sons, Inc, 435p.

Balaji, K.; Thirumaran, G.; Arumugam, R.; Kumaraguruvasagam, K.P. and Anantharaman, P. 2009. A Review on Marine Ornamental Invertebrates. World Applied Sciences Journal, 7(8): 1054-1059.

Barradas, J.I.; Amaral, F.M.D.; Hernández, M.I.M.; Flores-Montes, M.J. and Steiner, A.Q. 2010. Spatial distribution of benthic macroorganisms on reef flats at Porto de Galinhas Beach (northeastern Brazil), with special focus on corals and calcified hydroids. Biotemas, 23(2): 61-67.

Barreto, A.V. and Katsuragawa, M. 2008. Estádios de desenvolvimento dos órgãos reprodutivos dos machos de Panulirus echinatus Smith (Decapoda: Palinuridae). Revista Brasileira de Zoologia, 25(1): 74-82.

Batista, J.B.; Leonel, R.M.V. and Costa. M.A.J. 2009. Características populacionais de Microphrys bicornutus (Brachyura, Mithracidae) no fital Halimeda opuntia (Chlorophyta, Halimedaceae), em área recifal submetida à visitação humana, em João Pessoa, Paraíba. Iheringia, Série Zoologia, 99(1): 44-52.

Bezerra, L.E.A. and Almeida, A.O. 2005. Primeiro registro da espécie indo-pacífica Charybdis hellerii (A. Milne-Edwards, 1867) (Crustacea: Decapoda: Portunidae) para o litoral do estado do Ceará, Brasil. Tropical Oceanography, 33(1): 33-38.

Bouzon, J.L. and Freire, A.S. 2007. The Brachyura and Anomura fauna (Decapoda; Crustacea) in the Arvoredo Marine Biological Reserve on the Southern Brazilian Coast. Brazilian Journal of Biology, 67(2): 321-325.

Braga, A.A.; Fransozo, A.; Bertini, G. and Fumis, P.B. 2005. Composition and abundance of the crabs (Decapoda, Brachyura) off Ubatuba and Caraguatatuba, northern coast of São Paulo, Brazil. Biota Neotropica, 5(2): 1676-0603.

Bray, J.R. and Curtis, J.T. 1957. An ordination 
of the upland forest communities of southern Wisconsin. Ecological Monographs, 27: 325-349.

Brock, V.E. 1954. A preliminary report on a method of estimating reef fish populations. Journal of Wildlife Management, 18: 297308.

Caillaux, L.M. and Stotz, W.B. 2003. Distribution and abundance of Rhynchocinetes typus (Crustacea: Decapoda), in different benthic community structures in northern Chile. Journal of the Marine Biological Association of the United Kingdom, 83:143-150.

Calado, R.; Lin, J.; Rhyne, A.L.; Araújo, R. and Narciso, L. 2003. Marine ornamental decapods - popular, pricey, and poorly studied. Journal of Crustacean Biology, 23: 963-73.

Calado, T.C.S. 1996. Registro de Charybdis helleri (Milne- Edwards, 1867) em águas do litoral brasileiro (Decapoda, Portunidae). Boletim de Estudos de Ciências do Mar, 9: 175-180.

Castro, C.B. and Pires, D.O. 2001. Brazilian coral reefs: what we already know and what is still missing. Bulletin of Marine Science, 69(2): 357-371.

Cervigón, F.; Cipriani, R.; Fischer, W.; Garibaldi, L.; Hendrickx, M.; Lemus, A.J.; Márquez, R.; Poutiers, M.; Roijaina, G. and Rodriguez, B. 1992. Guia de Campo de las Especies Comerciales Marinas y de Aguas Salobras de la Costa Septentrional de Sur America. Rome, FAO, 513p.

Clark, P.F.; Ng P.K.L.; Fransen, C.H.J.M.; McLaughlin, P.A.; Dworschak, P.C. and Baba, K. 2008. A checklist of Crustacea Decapoda collected from Conic Island Cave and adjacent areas of Hong Kong. Journal of Natural History, 42 (9-12): 913926.

Clarke, K.R. 1993. Non-parametric multivariate analyses of changes in community structure. Australian Journal of Ecology, 18: 117-143.

Clarke, K.R. and Gorley, R.N. 2001. Software PRIMER v5. Plymouth, PRIMER-E. UK. Clarke, K.R. and Warwick, R.M. 1994. Change in marine communities: an approach to statistical analysis and interpretation. Plymouth, Plymouth Marine Laboratory, $144 \mathrm{p}$.

Coelho, P.A.; Almeida, A.O. and Bezerra, L.E.A. 2008. Checklist of the marine and estuarine Brachyura (Crustacea: Decapoda) of northern and northeastern Brazil. Zootaxa, 1956: 1-58.

Criales, M.M. 1984. Shrimps associated with coelenterates, echinoderms, and molluscs in the Santa Marta region, Colombia. Journal of crustacean biology, 4(2): 307-317.

Dajoz, R. 2005. Princípios de Ecologia. 7th ed., Artimed, Porto Alegre, 520p.

Denitto, F.; Moscatello, S. and Belmonte, G. 2009. Occurrence and distribution pattern of Palaemon spp. shrimps in a shallow submarine cave environment: a study case in South-eastern Italy. Marine Ecology, 30: 416-424.

Dominguez, J.M.L.; Bittencourt, A.C.S.P.; Leão, Z.M.A.N. and Azevedo, A.E.G. 1990. Geologia do Quaternário Costeiro do Estado de Pernambuco. Revista Brasileira de Geociências, 20: 208-215.

Dubinsky, Z. and Stambler, N. 2011. Coral Reefs: An Ecosystem in Transition. Dordrecht, Springer, 552p.

Edmunds, M.; Crozier, J.; Judd, A. and Gilmour, P. 2007. Victorian Subtidal Reef Monitoring Program: The Reef Biota at Wilsons Promontory Marine National Park (Volume 3). Parks Victoria Technical Series No. 50, Parks Victoria, Melbourne, 75p.

Edmunds, M.; Hart, S. and Ingwersen, C. 2005. Victorian Subtidal Reef Monitoring Program: The Reef Biota at Marine Protected Areas in the Twofold Shelf Region. Parks Victoria Technical Series No. 23. Parks Victoria, Melbourne, 70p.

Edmunds, M.; Hart, S.; Jenkins, S. and Elias, J. 2003. Victorian Subtidal Reef Monitoring Program: The Reef Biota at Wilsons Promontory Marine National Park. Parks Victoria Technical Series No. 6, Parks Victoria, Melbourne, 78p.

Feitosa, C.V.; Pimenta, D.A.S. and Araújo, M.E. 2002. Ictiofauna recifal dos Parrachos 
de Maracajú (RN) na área dos flutuantes: inventário e estrutura da comunidade. Arquivos de Ciências do Mar, 35: 39-50.

Feres, S.J.C.; Lopes, A.T.L. and Santos L.A. 2007. Primeiro registro de Charybdis hellerii (Milne Edwards, 1867) para o litoral Maranhense-Brasil (Crustacea, Decapoda, Portunidae). Boletim do Laboratório de Hidrobiologia, 20:77-82.

Fernandes, L.; Day, J.; Lewis, A.; Slegers, S. and Kerrigan, B. 2005. Establishing representative no-take areas in the Great Barrier Reef: Large-scale implementation of theory on marine protected areas. Conservation Biology, 19: 1733-1744.

Figueiredo, J.; Penha-Lopes, G.; Lin, J. and Narciso, L. 2008. Productivity and profitability of Mithraculus forceps. Aquaculture, 283: 43-49.

Gaeta, J.C.; Faria Júnior, E.; Aguiar, M.M. and Freire, A.S. 2011. The use of a nondestructive method to estimate the abundance of brachyuran crabs (Crustacea, Decapoda) in coastal islands of a marine protected area. Pan-American Journal of Aquatic Sciences, 6(4): 264-272.

Garcia, T.M.; Matthews-Cascon, H. \& Franklin-Junior, W. 2008. Macrofauna associated with branching fire coral Millepora alcicornis (Cnidaria: Hydrozoa). Thalassas, 24(1): 11-19.

Gasparini, J.L.; Floeter, S.R.; Ferreira, C.E.L. and Sazima, I. 2005. Marine ornamental trade in Brazil. Biodiversity and Conservation, 14: 2883-2899.

Gleibs, S; Mebs, D. and Werding, B. 1995. Studies on the origin and distribution of palytoxin in a Caribbean coral reef. Toxicon, 33: 1531-1537.

Hart Jr., C.W.; Manning, R.B. \& Iliffe, T.M. 1985. The fauna of Atlantic marine caves: Evidence of dispersal by sea floor spreading while maintaining ties to deep waters. Proceedings of the Biological Society of Washington, 98(1): 288-292.

Hayes, F.E.; Joseph, V.L.; Gurley, H.S. and Wong, B.Y.Y. 1998. Selection by two decapod crabs (Percnon gibbesi and Stenorhynchus seticornis) associating with an urchin (Diadema antillarum) at Tobago, West Indies. Bulletin of Marine Science, 63: 241-247.

Hayes, F.E.; Joseph, V.L.; Gurley, H.S. and Wong, B.Y.Y. 2006. Geographic variation in the association of decapod crabs with the sea urchin Diadema antillarum in the southeastern Caribbean Sea. Nauplius, 14(1): 31-35.

Hill, J. and Wilkinson, C. 2004. Methods for Ecological Monitoring of Coral Reefs. Townsville, Australian Institute of Marine Science, $117 \mathrm{p}$.

Hobbs III, H.H. 1994. Biogeography of subterranean decapods in North and Central America and the Caribbean region (Caridea, Astacidea, Brachyura). Hydrobiologia, 287: 95-104.

Huang, Z.; Brooke, B.P. and Harris, P.T. 2011. A new approach to mapping marine benthic habitats using physical environmental data. Continental Shelf Research, 31: 4-16.

Iliffe, T.M. and Bishop, R.E. 2007. Adaptations to life in marine caves. Fisheries and Aquaculture: Towards Sustainable Aquatic Living Resources Management, pp. 1-26. In: P. Safran (ed), Encyclopedia of Life Support Systems (EOLSS). Oxford: UNESCO-EOLSS Publishers.

Igarashi, M.A. 2010. Avanços no desenvolvimento tecnológico e status atual do cultivo de lagostas (Panulirus argus) do ovo ao tamanho comercial. Semina: Ciências Agrárias, 31(1): 269-280.

Krebs, C.J. 1994. Ecology. The Experimental Analysis of Distribution and Abundance. New York, USA, Harper Collins, 801p.

Krebs, C.J. 1998. Ecological Methodology. Melon Park, University of British Columbia, $620 \mathrm{p}$.

Laborel, J. 1970. Les peuplements de madréporaires des côtes tropicales du Brésil. Annales de l'Université d'Abidjan, 2(3): 1-260.

Leão, Z.M.A.N.; Kikuchi, R.K.P. and Viviane, T. 2003. Corals and coral reefs of Brazil. p. 9-52. In: J. Cortés (ed), Latin American Coral Reefs. Amsterdam, Elsevier.

Loebmann, D.; Mai, A.C.G. and Lee, J.T. 
2010. The invasion of five alien species in the Delta do Parnaíba Environmental Protection Area, Northeastern Brazil. Revista de Biología Tropical, 58(3): 909-923.

Maida, M. and Ferreira, B.P. 1997. Coral reefs of Brazil: an overview. Proceedings of the 8th International Coral Reef Symposium, Panama, 1: 263-274.

Manning, R.B. and Hart Jr., C.W. 1984. The status of the hippolytid shrimp genera Barbouria and Ligur (Crustacea: Decapoda): A reevaluation. Proceedings of the Biological Society of Washington, 97(3): 655-665.

Manso, V.A.V.; Corrêa, I.C.S. and Guerra, N.C. 2003. Morfologia e Sedimentologia da Plataforma Continental Interna entre as Praias Porto de Galinhas e Campos - Litoral Sul de Pernambuco, Brasil. Pesquisas em Geociências, 30(2): 17-25.

Mantelatto, F.L. \& Dias, L.L. 1999. Extension of the known distribution of Charybdis hellerii (A. Milne Edwards, 1867) (Decapoda, Portunidae) along the western tropical South Atlantic. Crustaceana, 72(6): 617-620.

Mantelatto, F.L.; Faria, F.C.R.; Biagi, R. and Melo, G.A.S. 2004. Majoid crabs community (Crustacea: Decapoda) from infralittoral rocky/sandy bottom of Anchieta Island, Ubatuba. Brazilian Archives of Biology and Technology, 47(2): 1-214.

Marshall, P. and Schuttenberg, H. 2006. A Reef Managers Guide to Coral Bleaching. Townsville, Great Barrier Reef Marine Park Authority, 165p.

Martínez-Iglesias, J.C. and García-Raso, J.E. 1999. The crustacean decapod community of three coral reefs from the Caribbean Sea (SW of Cuba): species composition, abundance and structure of the communities. Bulletin of Marine Science, 65: 539-557.

Mellin, C.; Andréfouët, S.; Kulbicki, M.; Dalleau, M. and Vigliola, L. 2009. Remote sensing and fish-habitat relationships in coral reef ecosystems: review and pathways for systematic multi-scale hierarchical research. Marine Pollution Bulletin, 58: 11-
19.

Melo, G.A.S. 1996. Manual de Identificação dos Brachyura (Caranguejos e Siris) do Litoral Brasileiro. São Paulo, Ed. Plêiade, 603p.

Melo, G.A.S. 1999. Manual de Identificação dos Crustacea Decápodo do Litoral Brasileiro: Anomura, Thalassinidea, Palinuridea e Astacidea. Sáo Paulo, Ed. Plêiade, 551p.

Micael, J.; Azevedo, J.M.N. and Costa, A.C. 2006. Biological characterization of a subtidal tunnel in São Miguel Island (Azores). Biodiversity and Conservation, 15: 3675-3684.

MMA - Ministério do Meio Ambiente; SECTMA - Secretaria de Ciência, Tecnologia e Meio Ambiente; CPRH Agência Estadual de Meio Ambiente e Recursos Hídricos. 2003. Diagnóstico do turismo nos municípios do Cabo de Santo Agostinho, Ipojuca e São José da Coroa Grande. Relatório Final. Recife, Brasil, 76p. Odum, E.P. and Barrett, G.W. 2007. Fundamentos de Ecologia. São Paulo, Thomson Learning, 616p.

Okuno, J. 1997. Crustacea Decapoda: Review on the genus Cinetorhynchus Holthuis, 1995 from the Indo-West Pacific (Caridea: Rhynchocinetidae). p. 31-58. In: B. Richer de Forges (ed.), Les Fonds Meubles des Lagons de Nouvelle-Calédonie (Sédimentologie, Benthos). Études \& Thèses, ORSTOM, Paris, vol. 3.

Oliveira, F.; Monteiro, P.; Afonso, C.; Veiga, P.; Bentes, L.; Calado, R. and Gonçalves, J.M.S. 2011. First record of Calcinus tubularis on the southern coast of Portugal (Crustacea: Decapoda: Anomura: Diogenidae). Marine Biodiversity Records, 4: e21.

Patton, W.K. 1967. Studies on Domecia acanthophora, a commensal crab from Puerto Rico, with particular reference to modifications of the coral host and feeding habits. Biological Bulletin, 132: 56-67.

Pielou, E.C. 1966. The measurement of diversity in different types of biological collections. Journal of Theoretical Biology, 13: 131-144. 
Randall, J.E. 1967. Food habits of reef fishes of the West Indies. Studies in Tropical Oceanography, University of Miami, 5: 655847.

Rhyne, A.L.; Penha-Lopes, G. and Lin, J. 2005. Growth, development, and survival of larval Mithraculus sculptus (Lamarck) and Mithraculus forceps (A. MilneEdwards) (Decapoda: Brachyura: Majidae): economically important marine ornamental crabs. Aquaculture, 245: 183-191.

Rocha, C.A.; Franklin-Júnior W.; Dantas, N.P.; Farias, M.F. and Oliveira, A.M.E. 1997. Fauna e flora acompanhantes da pesca da lagosta no nordeste do Brasil. Boletim Técnico-Científico do CEPENE, 5(1): 11-22.

Sarmento, V.C.; Barreto, A.F.S. and Santos, P.J.P. 2011. The response of meiofauna to human trampling on coral reefs. Scientia Marina, 75(3): 559-570.

Seytre, C. and Francour, P. 2008. Is the Cape Roux marine protected area (Saint-Raphaël, Mediterranean Sea) an efficient tool to sustain artisanal fisheries? First indications from visual censuses and trammel net sampling. Aquatic Living Resources, 21: 297-305.

Shannon, C.E. and Weaver, W. 1949. The Mathematical Theory of Communication. Urbana, University of Illinois Press, 117p.

Silva, E.C. and Barros, F. 2011. Macrofauna bentônica introduzida no Brasil: lista de espécies marinhas e dulcícolas e distribuição atual. Oecologia Australis, 15(2): 326-344.

Stevens, B.G. and Anderson, P.J. 2000. An association between the anemone, Cribrinopsis fernaldi, and shrimps of the families Hippolytidae and Pandalidae. Journal of Northwest Atlantic Fishery Science, 27: 77-82.

Thiel, M. and Vásquez, J.A. 2000. Are kelp holdfast islands on the ocean floor? Indication for temporarily closed aggregations of peracarid crustaceans. Hydrobiologia, 440: 45-54.

Udekem d'Acoz, C.d' 2001. First record of Janicea antiguensis (Chace, 1972) from the Cape Verde Islands and in the eastern Atlantic (Decapoda, Caridea,
Hippolytidae). Crustaceana, 73(9): 11631166.

Vanderklift, M.A.; How, J.; Wernberg, T.; MacArthur, L.D.; Heck Jr, K.L. and Valentine, J.F. 2007. Proximity to reef influences density of small predatory fishes, while type of seagrass influences intensity of their predation on crabs. Marine Ecology Progress Series, 340: 235-243.

Williams, A.B. 1984. Shrimps, lobsters and crabs of the Atlantic coast of the eastern United States, Maine to Florida. Washington, D.C., Smithsonian Institution Press, 550p.

Willis, T.J. 2001. Visual census methods underestimate density and diversity of cryptic reef fishes. Journal of Fish Biology, 59: 1408-1411.

Wilson, S.K.; Graham, N.A.J. and Polunin, N.V.C. 2007. Appraisal of visual assessments of habitat complexity and benthic composition on coral reefs. Marine Biology, 151: 1069-1076.

Wirtz, P. 2004. Four amphi-Atlantic shrimps new for São Tomé and Príncipe (eastern central Atlantic). Arquipélago: Life and Marine Science, 21A: 83-85.

Wirtz, P. and Udekem d'Acoz, C.d' 2008. Crustaceans associated with Cnidaria, Bivalvia, Echinoidea and Pisces at São Tomé and Príncipe islands. Arquipélago. Life and Marine Sciences, 25: 63-69.

Wirtz, P.; Melo, G.A.S. and De Grave, S. 2009. Symbioses of decapod crustaceans along the coast of Espírito Santo, Brazil. Marine Biodiversity Records, 2, e162: 1-9.

Zar, J.H. 1999. Biostatistical Analysis. Upper Saddle River, New Jersey, Prentice-Hall, 960p.
Submitted 30 May 2012 Accepted 26 October 2012 